\title{
The Construction of Nan Identity in the Context of Globalization through Festival Long Boat Race
}

\author{
Suthira Kanatham \\ Faculty of Social Sciences \\ Chiang Mai University \\ Chiang Mai, Thailand \\ naysuthira@gmail.com
}

\begin{abstract}
Traditional boat race Nan has a long history of over 200 years. Characteristically outstanding, which represents the identity of the area linked to the history of the community. The expression of strong relationships with people in the community. In addition, today's long boat race has become an annual national priority. The boats are the most attended and have the most royal trophy in Thailand. The long boat competition has been promoted so that more people are attracted to the tourism of Thailand, linked to the identity of the Nan people. However, such views and past studies on the tradition of Nan boat race sport are important, but the issue of long boat competition is a tool for creating a social integration in the everyday life of the Nan people. But lack of link to the process of creating identity of the Nan people because of interaction with globalization. It involves a wide range of people, both in and out of the area, as well as changes in composition. In the long tradition of the boat race in Nan province is a sport. As a result, the long boat race is a more complex phenomenon and cannot be explained by the traditional way of studying it anymore. So, this article proposes that Nan's long boat race has been re-interpreted and is being used by a variety of people in the political of identity space. To present the Nan as a "dialectic" process between local communities and globalization. It is expressed in various operational levels that make the long boat race and Nan people not limited to provincial and cultural areas.
\end{abstract}

Keywords - long boat racing festival, construction of identity, globalization, dialectic

\section{INTRODUCTION}

Meuang Nan or Nuntaburi is located at the bank of Nan River flowing from the northern mountain. The mountain is just like a wall protecting from enemies. Strategically Nan is the significant area and the protector benefit of country [1, p. 22-23]. Moreover, it is known as the origin of the important river called Nan River that has nourished Nan people and originated the most essential tradition well known as Boat racing Tradition for more than 200 years.

In the past, long boat racing in Nan province appeared as a traditional custom and community recreation. It promoted harmony among villagers and supported the belief in Buddhism of Nan people. According to local culture the boat represented a vehicle for carrying people to make merit. It supported people's aim to attain enlightenment according to Buddhist doctrine [2]-[4]. Hence, traditional long boat racing complemented the cultural meanings, historical contexts and beliefs of Nan people. Also, it expressed their romanticized local knowledge. The decorations on the long boat exemplified their cultural beliefs and knowledge. For instance, the colourfully-painted boats made from whole tree trunks and adorned with an elaborately-crafted Naga head at the prow represented the ancient belief in "Naga" which combined the story of Nan River and the belief in Buddhism of Nan people [5].

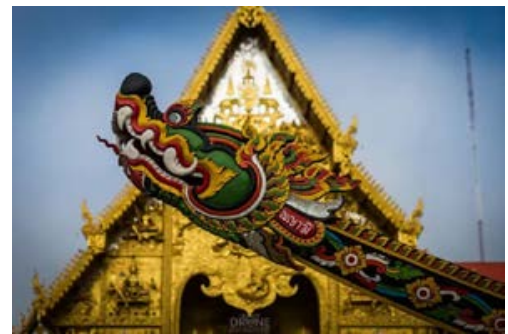

Fig. 1. Ancient boat named "Phayakhu" (พญาฆึ), the biggest racing boat in Nan Province.

Long boat racing became a national festival after 1979. It has changed from a traditional custom and community amusement to a "festival" and become more of a sport. It began from the policy management of local traditions by Thai government offices. That has resulted in adding sport forms to local long-boat racing, such as setting regulations and qualifications and appointing referees. They have also added rewards and trophies. Thus, it became more of a sports contest, and well-known as a national Thai festival. Nan long-boat racing has been organized by several entities, especially the provincial and national government offices. In addition, the festival has been promoted by national media such as television. All these developments have transformed the local traditions and power relationships among local people. For instance, local gambling on long-boat races has been restricted by new regulations, while the traditional pattern of boat racing has become more competitive, losing touch with its cultural background [3], [6].

Additionally, the application of boat building science has diminished the important of local knowledge: long boats have been re-designed to be more modern. Meanwhile, several villages have applied sports science to develop the training of crews in physical fitness and muscular strength. As a result, 
there are many new boat clubs supported by private organizations or businessmen. These groups are not part of the local community. Now there are more than 200 long boats in Nan province [7]. This is how traditional long-boat racing has finally transformed into a sport and a national festival.

However, the transformation is not undisputed. There are attempts by local people to preserve the ancient traditions of long boat racing. For instance, the local group in Waing Sa district or Tha Wang Pha district of Nan restored long-boat racing in its traditional form, and many local offices also attempted to promote the traditional identity of Nan long-boat racing [8]. On the other hand, the Thai Health Promotion Foundation has promoted a campaign for Nan long boat racing to be "non-alcohol". Thus, there are discrepancies between traditional long-boat racing and modern long-boat racing in Nan province [3].

In the meantime, long-boat racing has become a 'negotiated space' where different power groups intersect - communities, business groups, provincial authorities and national government offices. There is a struggle for economic, political, and socio-cultural interests among these groups, and a cultural politics dimension within the long-boat racing festival of Nan province in the neoliberal context of modern sport. This paper aims to explore the politics of identity who have been engaging with the long boat racing festival in Nan province. In addition this paper also needs to link the process of creating identity of the Nan people as a result of interaction with globalization. It involves a wide variety of people in both inside and outside the area. To expose the dynamics of people from the past to the present, living by living the Nan River is nourished through the tradition of the long boat race of Nan.

\section{RESEARCH METHODOLOGY}

For the study, the researcher studied through several methods as follows: (1) documentary research for studying the structural factor of boat racing tradition: people and organization taking part in tradition, competition area, competition process, competition timing, number, format, and classification of boat racing competition, rule, and budget. Historically, the boat racing tradition could be divided into 3 periods, but the study focused on the first and second period (during 2359 to $2521 \mathrm{BE}$ ). The significant evidence being discovered in this period is the old boat that later had become the historical boat of Nan province. The research began to study from this period till the present. For the study in this period, the researcher studied from document, picture and other primary documents related with the history of Nan and boat racing tradition. At the same time, the researcher studied through secondary document such as research, thesis and other reference documents, (2) focus group: the researcher interviewed the number of interviewees is 15 people related with both racing tradition according to the study objectives, (3) in-depth interview: the researcher focused on one by one for collecting data, thinking method and understanding leading to building the meaning of boat racing tradition in Nan, and (4) observation: the researcher observed every steps; before competition, during competition and after competition. In addition, other factors of boat racing tradition (such as advertising and brochures, etc.) were also observed.

\section{RESEARCH RESULTS}

\section{A. History of Long Boat Racing in Nan Province}

For the study, the researcher studied the development of boat racing tradition through 2 conditions; (1) the shape of boat and (2) the international standard rule. The study was divided into 3 periods as follows:

The first period: it started from discovering the oldest evidence; boat called as Sia Toa Ta Lor boat until developing from boat called Khi kha ya to Hong boat. In 1978 BE (1816 1918 CE), the most secure transportation in Nan was river. The way of life related with boat was seen easily. At that time, the main purpose of boat was transportation especially travelling by boat to participate merit activities in the Buddhist temples. After merit activities finished, people took boat into competition for fun. The data (Nan boat racing program for King Rama 9 Memorial) indicated that community's leaders and local rich men were the main supporters to build boat that made from the stick tree (local people believed that this tree was lasting more than others). At that time, boat racing tradition was organized by two groups; Nan leader and local people [3].

The second period: it started from 1979 - 2006 CE. The boat racing tradition was organized through international rule and there was award from King for the winner. In 1936, the rule was changed such as starting and finish point. In 1979, competition fields increased respectively, strictly rule was necessary [9]. However, in the present, all rules were changed according to condition of each competition fields, but still under Nan Boat Racing Association [10].

The third period: from 2007 till now, boat building process was developed through science such as boat weigh calculation, boat shape creative, and so on. The present boat had become new invention. Moreover, the waterman was improved through sport science such as nutrition and physiology etc. Mostly, people focused on building physical ability such as muscle strength, breathing ability, physical speed, bodily flexibility, and relation of all body's parts. At the same time, government's policy focusing on promote tourism and sports through several media such as television and internet, affected towards changing form of boat racing tradition. In the previous time, boat racing tradition used to be instrument leading to entertainment, community harmony and Buddhist promotion, but now it had become fully competition aimed at the winner and honor. And also gambling had become very popular among local people. So the international rule was very necessary for the competition.

\section{B. Dialectic Process between Local communities and}

\section{Globalization}

At the present, Nan boat racing tradition has been promoted as national and international tournament. It was still close system (allow the local waterman only), well known as the oldest tradition in Thailand, and also related in several functions; history, way of life, economy and policy. There are 
five significant features of this tradition that have attracted tourists from around the world; 1 . The most King cups 2. The oldest boats 3.the most beautiful boats and 4. The most number of boats in the country.

In addition, Department of Society and Human Security Development has permitted child from the juvenile detention center to participate the tournament. Moreover, the private and government have promoted youth waterman from provincial level into national level [11].

After Nan boat racing tradition having been push forwards into government policy and materialism, it has become fully tourist industry. Nan has been developed into famous city named as a living old city. Several organizations, private and government, have co-operated to promote the tradition up to national and international level. At the present, Nan boat racing tradition has become a symbol of the city as national culture building harmony among Thais.

At the same time, there has been conflict among individual group and local community to express as the cultural owner, and tried to write their own history without any relation with government influence. Local people has tried to organize boat racing tournament in their own community on the main annual festival such as new year festival in Ban Khung, Wiangsa district, that built relationship among close communities through boat racing tournament. Moreover, they could make money from variety activities such as traditional dancing and local fairs. However, they still have kept the previous objective as competition among communities. Sometimes, they have organized boat racing out of tournament at small dam in the village (during Songran Festival in April organized by Chaisathan Mulnicipality, Nan) in order to welcome their children coming from several cities of Thailand.

For author's opinion, above mentioned phenomena is action of some people to build community's identity through tradition as instrument of politic, economic, culture and society. Co-operation among government, private and community could reserve the tradition, particularly; in case of Chaisathan Mulnicipality, even though the boat racing tradition has been organized out of tournament (Songran Festival) but it has been working because of local dam having full of water that is enough for tournament. The rule under government has been chosen for the tournament. It may show that even though the community could run their own activity but it is still side by side with government.

However, building identity through these local history indicates discontinuity, deprivation, diversity and without unity, that shows power relation and conflict hidden under Nan boat racing tradition and dairy life of Nan people towards their own culture, also under globalization [12], [13].

\section{The Construction of Nan Identity in the Context of Globalization through Festival Long Boat Race}

The tradition of boat racing in Nan Province is regarded as one of the most important traditions of the province. The provincial motto gives it precedence. It can be said that this tradition has a diverse group of people who engage with it. This article will try to distinguish them, by grouping the people who engage in all 4 levels: the community level; the provincial level; the state level; and the international organization level.

Before explaining the picture, the author recognizes that these groups are not completely separate. There are intricate internal links in the relationship structure, for example kinship and relationships that overlap in economic and political interests. From the first level, we can see that there are people in the community that are related to this tradition. At village level they include monks, trainers, ritualists, boat builders, paddlers, cheerleaders, housewives, as well as boat crews. There may be local investors who may come to finance the construction of the boat. The key local agencies that coordinate at the provincial level are the district municipalities, coordinating with the Community Racquet Board and Health Promotion and Health Promotion Office, Provincial Administrative Organization, private enterprises and local politicians. At the district level, a long-standing boat race board will be set up to run and compete. It depends on local management. For example, in the district of Wiang Sa in 2012, the board organized a total of 19 races drawing all relevant departments within the district into the tradition. For example, there is a first aid department, peacekeeping field radio, field spokesman, etc.

At provincial level Nan is the main host city for centralized operations. There is a parallel partnership with Nan municipality, the Nan Thai Boat Racing Association and the Tourism Authority of Thailand (TAT). At 1 December 2016 there was a boat race and parade of 89 boats in Nan to honour King Rama 9. There are a number of key organizations that support this. Provincial Administrative Organization, Military Region 38, Nan Municipality, Nan Boat Racing Association, Cage Brewer Network, Health Promotion Fund, Hongsa Power Company Limited, Big C Nan Branch, Company Phra Praduvawit Ltd., Nok Air, AirAsia, Phakkasatran Hotel, Chayit Nan Partnership, Kasikorn Bank, Government Savings Bank And some restaurants in Nan [14]. Nationally, central government agencies have linked Nan's long-boat policy with provincial policy. The central policy that directly affects Nan is Tourism policy. As a result of the announcement of Nan Province as a "Living old city", Nan is known for its tourism. In the last quarter of 2014, Nan was selected among 12 hidden gem provinces by the Tourism Authority of Thailand, attracting more visitors. At the national level, the organizations that engage are larger. At the international level, under the ASEAN Agreement, Nan is aligned with regional and international policy in inter-regional relations by interacting with neighboring countries such as Lao PDR and Vietnam. In 2013, there will be boat races between the 3 countries, on 4 rivers: Laos, Thailand and Vietnam (Nan river, Hong river, Da river and Kan river) to jointly preserve the tradition of boat racing among ASEAN countries as part of social and cultural cooperation. It is evident that central government policy is at the core. However, the community of Nan province itself also plays an important role in determining the direction of the long-boat race in the province. The longboat competition area in Nan is a negotiated space for all power groups to interpret and define meaning or power. 


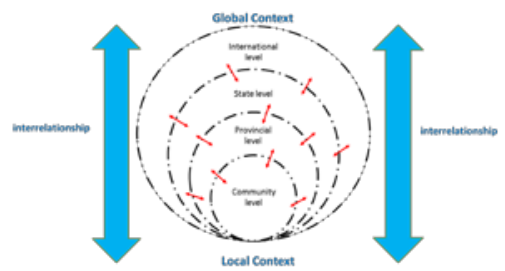

Fig. 2. Showing multiple powerful groups and their cultural practices which participate in long boat racing space.

\section{CONCLUSION}

The traditional long-boat race of Nan province at the beginning was a game activity or tradition of the local community, depending on the traditional social values of the community. Today it has developed into a regular sport festival of Nan Province and expanded into the national and international arenas. It is evident that in such a forum, there are multiple levels of participation, including local, state, private, etc., that benefit, including economically, socially and politically. Interactions among various interest groups are fluid and therefore have implications for cultural politics. There have been some studies on the traditions of the long boat race in Nan province focusing on its history, community resource management, and the view that such a tradition represents a single area of participatory power and community value systems. But there is a lack of openness to the view of the power relations of the diverse people who are involved in the definition of the meaning and tradition of the long-boat race in the context of neoliberalism. This is a new perspective on the culture which is more fragmented, with more powers, regulations and frameworks. There are power relationships that may be more contradictory than a common value system. And culture is about creating meaning based on specific contexts including the scramble between the various groups. This makes the meaning of culture not fixed.

Because this article is preliminary the author wishes to make note of the issues that might affect future study. The first issue is of agricultural companies that support the farmers in Nan area, such as corn and rubber plantations, who contribute to the long-boat race. And how do groups such as Thai Beverage Public Company Limited or Singha Corporation Co. Ltd. get involved, given that Nan is the first province in Thailand to hold a long-boat race as "no alcohol"? The next issue is the group of rowers especially the youth, because some of them come from different provinces. However, when the season is over, boating will be back to the village itself or boating to other areas. At the end of the season the province will also provide rowers to other boats in the central region.

\section{ACKNOWLEDGMENT}

I would like to express my sincere gratitude to my advisor, Yos Santasombat for his valuable guidance and suggestions in this research project. I would like to say thank you to Aranya Siriphon and Pairoj Kongtaweesak for their academic supports and advices. I want to thank my colleagues in Faculty of Social Sciences, Chiang Mai University and Chiang Rai Rajabhat University for various kinds of help.

\section{REFERENCE}

[1] C. Jeenchawna, “An Analytical Study of Nan’s Society from Anachak Lakkham Law (1852-1908),” M. S. thesis, Thai History, Graduate School, Srinakharinwirot University, Bangkok, Thailand, 2006.

[2] A. Pongrungsie, "The process of cultural resource management : a case study on traditional long boat race of Ban Donchai, Klangwiang SubDistrict, Wiangsa District, Nan Province,” 2007.

[3] S. Phonsantikul, "Management of Local Traditional for Tourism: A Case Study of Nan Traditional Boat Racing,” Master of Arts Program in Cultural Management (Interdisciplinary Program), Graduate School, Chulalongkorn University, 2012.

[4] G. Satean and P. Sirasoonthorn, "Development of Social Innovation for Creatively Health Promotion in the Traditional boat Racing in Wiang Sa District, Nan Provice,” Narasuan University, 2013.

[5] R. Barton, "Royal Trophy Nan Boat Races,” Thailand Discovery, 2016. [Online]. Available: https://www.thailanddiscovery.info/thailandfestivals-longboat-racing/.

[6] W. Panyavuttakul and S. Kluanklad, "A study of a Connection between Grambling and Long Boat Racing,” Thai Health Promotion Foundation, 2013.

[7] C. Chinmaneevong, "Nan keen to avoid being swamped,” Bangkok Post, $\begin{array}{lll}\text { Jul. } & \text { 8th, } 2005 . & \text { Anline]. }\end{array}$ http://www.bangkokpost.com/print/616352/. [Accessed Feb. 10, 2016].

[8] A. Saisoong, Interview, Jan. 1, 2018.

[9] Y. Yodsook, History of Nan boat racing festival: Racing boat of Nan from documents, legend and narrative. Nan: Prakruphuttamonchotikhon Foundation, 2009.

[10] S. Machai, Interview, Oct. 31, 2016.

[11] Nan Advertising office. “ชาวน่านร่วมต้อนรับแสดงความยินดีกับน้อง แอม วนิดา ธรรมราช นักกีฬาเหรียญทองเรือพายซีเกมส์ ครั้งที่ 28 ที่ประ สิงคโปร์,” [Online]. Available: http://thainews.prd.go.th/website_th/news/news_detail/. [Accessed Nov. 10, 2016].

[12] G. W. Azoy, Buzkashi, Game and Power in Afghanistan, 3rd ed. Waveland Press, 2012.

[13] L. N. Adrover, "Festival Encounters: Value Logics and the Political Economy of Cultural Production in Ghana," Ph. D. dissertation, Field of Anthropology, Evanston, Illinois, 2014.

[14] Municipality of Nan, “สูจิบัติประเพณีแข่งเรือจังหวัดน่านนัดปิดสนาม ประจำปี 2559 [The Schedule of Nan Long Boat Racing in 2016],” Mimeograph, 2016. 